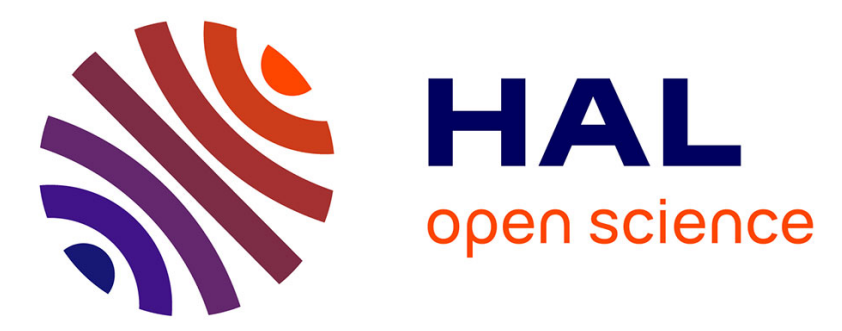

\title{
Towards the synthesis of mixed oxides with controlled stoichiometry from Prussian blue analogues
}

\author{
Virgile Trannoy, Amélie Bordage, Jordan Dezalay, Romuald Saint-Martin, \\ Eric Rivière, Patricia Beaunier, Cédric Baumier, Camille La Fontaine, Giulia \\ Fornasieri, Anne Bleuzen
}

\section{To cite this version:}

Virgile Trannoy, Amélie Bordage, Jordan Dezalay, Romuald Saint-Martin, Eric Rivière, et al.. Towards the synthesis of mixed oxides with controlled stoichiometry from Prussian blue analogues. CrystEngComm, 2019, 21 (23), pp.3634-3643. 10.1039/c9ce00427k . hal-02187860

\section{HAL Id: hal-02187860 https://hal.science/hal-02187860}

Submitted on 16 Aug 2021

HAL is a multi-disciplinary open access archive for the deposit and dissemination of scientific research documents, whether they are published or not. The documents may come from teaching and research institutions in France or abroad, or from public or private research centers.
L'archive ouverte pluridisciplinaire HAL, est destinée au dépôt et à la diffusion de documents scientifiques de niveau recherche, publiés ou non, émanant des établissements d'enseignement et de recherche français ou étrangers, des laboratoires publics ou privés. 


\title{
Journal Name
}

\section{ARTICLE TYPE}

Cite this: DOI: $10.1039 / x x x x x x x x x x$

\section{Towards the synthesis of mixed oxides with controlled stoichiometry from Prussian Blue analogues ${ }^{\dagger}$}

\author{
Virgile Trannoy, ${ }^{a \ddagger}$ Amélie Bordage, ${ }^{* a}$ Jordan Dezalay, ${ }^{a \S}$ Romuald Saint Martin, ${ }^{a}$ Eric \\ Rivière, ${ }^{a}$ Patricia Beaunier, ${ }^{b}$ Cédric Baumier, ${ }^{c}$ Camille La Fontaine,${ }^{d}$ Giulia Fornasieri, ${ }^{a}$ \\ and Anne Bleuzen ${ }^{a}$
}

Received Date

Accepted Date

DOI: $10.1039 / x x x x x x x x x x$

www.rsc.org/journalname
Controlling the synthesis of mixed oxides is of great interest since their stoichiometry influences the properties. We present here the transformation of the $\mathrm{Co}_{4}\left[\mathrm{Fe}(\mathrm{CN})_{6}\right]_{2.7}$ Prussian Blue Analogue (PBA) into the mixed $\mathrm{Co}_{1.8} \mathrm{Fe}_{1.2} \mathrm{O}_{4}$ spinel oxide, with a detailed characterization of the final phase (obtained by calcination in air at $900^{\circ} \mathrm{C}$ during 2 hours) and an emphasis on the calcination process by TDA/TGA, X-ray diffraction, (High-resolution) TEM and Energy-filtered TEM. Singlecrystalline particles with an homogeneous distribution of $\mathrm{Fe}$ and $\mathrm{Co}$ ions within each particle are observed, with the same Co:Fe ratio as in the PBA. The calcination mechanism is a 2-steps transformation, with first the elimination of water molecules and then the cyanide decomposition. XRD and TEM at intermediate temperatures additionally show the occurrence of a phase separation between $500^{\circ} \mathrm{C}$ and $850^{\circ} \mathrm{C}$ before the formation of the single final phase. We demonstrate also through the calcination of intermediate PBAs between $\mathrm{Co}_{4}\left[\mathrm{Fe}(\mathrm{CN})_{6}\right]_{2.7}$ and $\mathrm{Co}_{4}\left[\mathrm{Co}(\mathrm{CN})_{6}\right]_{2.7}$ that this synthesis route leads to the perfect control of the oxide stoichiometry through the control of the PBA. The versatility of this synthesis route is finally illustrated through the successful synthesis of $\mathrm{Co}_{1.8} \mathrm{Fe}_{1.2} \mathrm{O}_{4}$ nanoparticles (diameter $\sim 5 \mathrm{~nm}$ ) from PBA nanoparticles confined within the pores of a mesoporous silica monolith.

\section{Introduction}

Spinel ferrites are transition metal oxides of general formula $\mathrm{M}_{x} \mathrm{Fe}_{2-x} \mathrm{O}_{4}$, where $\mathrm{M}$ can be a transition metal, an alkali earth element or even a rare-earth element. The interest for these compounds significantly grew in the past decade thanks to the wide range of applications of these materials, e.g. in catalysis, depollution of water, energy storage (batteries, supercapacitors...), gas sensors, medicine applications, magnetic devices and data storage.1111 Such a wide range of applications arises from the price-

\footnotetext{
a ICMMO, Université Paris-Sud, Université Paris-Saclay, CNRS, 15 rue Georges Cl'emenceau, 91405 Orsay Cedex, France. Tel: +33 1691570 55; E-mail: amelie.bordage@u-psud.fr

${ }^{b}$ Sorbonne Université, CNRS, Laboratoire de Réactivité de Surface, LRS, F-75005 Paris, France.

${ }^{c}$ Centre de Sciences Nucléaires et de la Matière, Université Paris-Sud, CNRS/IN2P3, Université Paris-Saclay, 91405 Orsay Cedex, France.

d Synchrotron SOLEIL, Saint Aubin, 91190 Gif-sur-Yvette, France.

$\dagger$ Electronic Supplementary Information (ESI) available: [Evidence by Infra-Red spectroscopy of a thermally-induced charge transfer in $\mathrm{CoFe}$ below $300^{\circ} \mathrm{C}$; Complete set of X-ray diffraction patterns between $300^{\circ} \mathrm{C}$ and $900^{\circ} \mathrm{C}$.

$\ddagger$ Present address: Institut des Matériaux Jean Rouxel, Université de Nantes, CNRS, 2 rue de la Houssinière, BP 32229, 44322 Nantes Cedex 3, France.

$\S$ Present address: ISMO, Université Paris-Sud, Université Paris-Saclay, CNRS, 15 rue Georges Clémenceau, 91405 Orsay Cedex, France.
}

less rich versatile chemistry of the spinel family, which offers the opportunity to adjust the stoichiometry to reach tailor-made properties. However, it is well-known that the properties of a spinel ferrite depends on its stoichiometry $[12,[15]$ and for a given targeted stoichiometry, also on the synthesis process.1-3]16-24 Therefore many efforts have been devoted to the improvement of the synthesis process of the ferrite spinels in order to better control their stoichiometry and so their property.

One interesting way is the calcination in air of a precursor, whose stoichiometry, structure and synthesis are known and controlled. Prussian Blue Analogues (PBA) thus appear as a promising sacrificial compound, as their synthesis is well established and enables a full control of the PBA stoichiometry. They are coordination polymers with general formula $\mathrm{A}_{p}\left[\mathrm{~B}(\mathrm{CN})_{6}\right]_{q} \cdot \mathrm{H}_{2} \mathrm{O}(\mathrm{A}, \mathrm{B}=$ transition metals) with a well-defined organization of the metallic cations at the atomic scale: the two transition metals are linked through a cyanide bridge, with an homogeneous repartition of the two transition metals at the atomic scale, thus leading to a face-centered cubic structure. Several studies already showed that when calcinated in air, PBAs (either bi- or trimetallic) are transformed into ternary or spinel oxides. $\frac{4|5 / 25| 38}{4}$

In the particular case of Co ferrites, the $\mathrm{Fe}_{1.8} \mathrm{Co}_{1.2} \mathrm{O}_{4}$ spinel oxide was obtained from the $\mathrm{Fe}_{3}\left[\mathrm{Co}(\mathrm{CN})_{6}\right]_{2} \mathrm{PBA}$ for different 
calcination conditions. ${ }^{4 \mid 29}$ Nevertheless, these studies focused on the final product and its properties with no or few description of the PBA $\rightarrow$ spinel transformation process itself. Also, it is wellknown that the Fe-rich $\left(\mathrm{CoFe}_{2} \mathrm{O}_{4}\right)$ and the Co-rich $\left(\mathrm{FeCo}_{2} \mathrm{O}_{4}\right)$ spinels do not present the same thermodynamic stability and that their synthesis is not possible over the same temperature range : using a low-temperature co-precipitation method, it was shown that $\mathrm{CoFe}_{2} \mathrm{O}_{4}$ was formed at $300^{\circ} \mathrm{C}$, while $\mathrm{FeCo}_{2} \mathrm{O}_{4}$ could be formed as a single phase only around $900^{\circ} \mathrm{C} .12 .16$ Therefore we undertook the detailed study of the formation of the $\mathrm{Co}_{1.8} \mathrm{Fe}_{1.2} \mathrm{O}_{4}$ (called CoFe-Ox in the following) Co-rich counterpart of the $\mathrm{Fe}_{1.8} \mathrm{Co}_{1.2} \mathrm{O}_{4}$ spinel ${ }^{4 \mid 29}$ from the $\mathrm{Co}_{4}\left[\mathrm{Fe}(\mathrm{CN})_{6}\right]_{2.7}$ PBA (called CoFe in the following). In addition to the characterization of the final phase by X-Ray Diffraction (XRD) and both high-resolution and energy-filtered Transmission Electron Microscopy (TEM), we present a detailed study of the calcination process itself by thermodifferential/thermogravimetric analyses (TDA/TGA), XRD and TEM. From these results, we extend this thermal treatment optimized for a bimetallic PBA (i) to the formation of spinel ferrites of intermediate compositions between $\mathrm{Co}_{1.8} \mathrm{Fe}_{1.2} \mathrm{O}_{4}$ and $\mathrm{Co}_{3} \mathrm{O}_{4}$, their stoichiometry being controlled by the precursor PBA one, and (ii) to the formation of single-cristalline $5 \mathrm{~nm}$-particles of the $\mathrm{Co}_{1.8} \mathrm{Fe}_{1.2} \mathrm{O}_{4}$ spinel from the calcination of CoFe nanoparticles confined within the pores of a mesoporous silica monolith.

\section{Experimental}

\subsection{Syntheses}

The CoFe powdered $\mathrm{Co}_{4}\left[\mathrm{Fe}(\mathrm{CN})_{6}\right]_{2.7}$ PBA was prepared as already described elsewhere. $\frac{39}{400} \mathrm{~mL}$ of an aqueous solution of potassium hexacyanoferrate(III) (concentration of 2.5.10 ${ }^{-3}$ mol. $\mathrm{L}^{-1}$ ) were added dropwise during 3 hours and under stirring to $100 \mathrm{~mL}$ of an acidic aqueous solution of Co(II) nitrate $\left(5.10^{-2} \mathrm{~mol} . \mathrm{L}^{-1}, \mathrm{pH}=3\right)$. The resulting precipitate was centrifugated (15 minutes at 8000 rot. $\mathrm{min}^{-1}$ ), washed three times with distilled water and centrifugated again. Finally it was allowed to dry in air at room temperature.

Intermediate chemical compositions between CoFe and the monometallic $\mathrm{Co}_{4}\left[\mathrm{Co}(\mathrm{CN})_{6}\right]_{2.7}$ PBA (called CoCo) were synthesized by a progressive replacement of $\mathrm{Fe}$ by Co in the starting $\left[\mathrm{Fe}(\mathrm{CN})_{6}\right]^{3-}$ solution. The formula of the targeted PBA are $\mathrm{Co}_{4}\left[\left(\mathrm{Co}_{0.25} \mathrm{Fe}_{0.75}\right)(\mathrm{CN})_{6}\right]_{2.7}$ (called $\mathrm{Co}(\mathrm{Co} 25) \mathrm{Fe}), \mathrm{Co}_{4}\left[\left(\mathrm{Co}_{0.50} \mathrm{Fe}_{0.50}\right)(\mathrm{CN})_{6}\right]_{2.7}$ (called $\mathrm{Co}(\mathrm{Co50}) \mathrm{Fe}$ ) and $\mathrm{Co}_{4}\left[\left(\mathrm{Co}_{0.75} \mathrm{Fe}_{0.25}\right)(\mathrm{CN})_{6}\right]_{2.7}$ (called $\mathrm{Co}(\mathrm{Co} 75) \mathrm{Fe}$ ).

To obtain the $\mathrm{CoFe} \mathrm{PBA} / \mathrm{SiO}_{2}$ nanocomposite (called NanoCoFe), a $\mathrm{Co}^{2+}$-containing mesoporous silica monolith 40 is impregnated with an acidic $\left[\mathrm{Fe}(\mathrm{CN})_{6}\right]^{3-}$ solution using the double-solvent method. 41,43 This technique was already successfully applied to the synthesis of several PBAs as nanoparticles. 35 44 47 In previous studies, we also showed that all the Co cations initially present in the silica monolith are transformed in $\mathrm{PBA} 4 \sqrt{48}$ and that the PBA particles are entirely confined within the pores of the silica monolith. $\frac{40}{}$ The synthesis of the mesoporous silica monolith is described in Refs. 34, 39, 43 and 44.

\subsection{Thermal treatment}

After an optimization of the thermal treatment, 49 the transformation of CoFe into oxide (called CoFe-Ox) could be achieved by heating in air up to $900^{\circ} \mathrm{C}$, with a heating rate of $5^{\circ} \mathrm{C} \cdot \mathrm{min}^{-1}$ followed by a 2-hours plateau at the targeted temperature. The same conditions of calcination were applied to the three Coenriched PBAs (Co(Co25)Fe, Co(Co50)Fe and Co(Co75)Fe), leading to the three oxides $\mathrm{Co}(\mathrm{Co25}) \mathrm{Fe}-\mathrm{Ox}, \mathrm{Co}(\mathrm{Co50}) \mathrm{Fe}-\mathrm{Ox}$ and Co(Co75)Fe-Ox.

To better understand the PBA-to-oxide transformation, a series of samples were also prepared from CoFe by heating at intermediate temperatures between room-temperature and $900^{\circ} \mathrm{C}$ (also with a $5^{\circ} \mathrm{C} \cdot \mathrm{min}^{-1}$ heating rate and a 2-hours plateau). The chosen temperatures are $300^{\circ} \mathrm{C}, 400^{\circ} \mathrm{C}, 500^{\circ} \mathrm{C}, 600^{\circ} \mathrm{C}, 700^{\circ} \mathrm{C}$, $750^{\circ} \mathrm{C}, 800^{\circ} \mathrm{C}$ and $850^{\circ} \mathrm{C}$; the corresponding oxides are called CoFe-TTXXX, where TT means Thermal Treatment and XXX is the corresponding temperature.

\subsection{Materials characterizations}

Elemental analyses were performed at the Service Central d'Analyses of the CNRS (Solaize, France).

Thermodifferential (TDA) and thermogravimetric (TGA) analyses were performed under air with a flow rate of $100 \mathrm{~mL} \cdot \mathrm{min}^{-1}$ and a temperature ramp of $5^{\circ} \mathrm{C} \cdot \mathrm{min}^{-1}$ up to $900^{\circ} \mathrm{C}$ using a TA Instruments SDT Q600 apparatus.

X-ray diffraction patterns were recorded using a Phillips PAN X'Pert PRO MPD X-ray diffractometer ( $\mathrm{Cu} \mathrm{K} \alpha_{1} ; \lambda=1.5418 \AA$ ). An aluminum sample holder was used for CoFe , the three intermediate compositions and the corresponding oxides. No background subtraction was performed on the XRD patterns. The lattice parameters were extracted using a simple Lebail fit for a $F m 3 m$ space group in the case of the precursor PBA and a $F d \overline{3} m$ space group in the case of the oxides.

Transmission Electron Microscopy (TEM) images were recorded using a JEOL JEM 100CXII electron microscope operating at an acceleration voltage of $100 \mathrm{kV}$, whereas High-Resolution TEM (HR-TEM) images and EDX spectroscopy were performed using a JEOL JEM 2011 apparatus equipped with a LaB6 filament and operating at $200 \mathrm{kV}$; the images were collected using a 4008x2672 pixel CCD Camera (Gatan Orius SC1000) (LRS, Paris, France). EDX measurements were performed for different particles; the results are very close among the probed particles, so the given composition is representative of the whole sample. Additional images were taken using the FEI Tecnai G2 20 JANNuS-TEM (CSNSM/SCALP, Orsay, France) operating at an acceleration voltage of $200 \mathrm{kV}$ with a spatial resolution of $0.23 \mathrm{~nm}$; it is equipped with a GIF (Gatan Imaging Filter) Tridiem 863 , which was used to acquire the energy-filtered images.

Magnetic measurements were recorded at room temperature with an MPMS-5S superconducting quantum interference device (SQUID) magnetometer for the four Co-Fe oxides (CoFeOx, Co(Co25)Fe-Ox, Co(Co50)Fe-Ox and Co(Co75)Fe-Ox). The samples were in powder form and placed in a capsule.

Fe and Co K-edges X-ray absorption spectroscopy was performed on CoFe-Ox, Co(Co25)Fe-Ox, Co(Co50)Fe-Ox and 

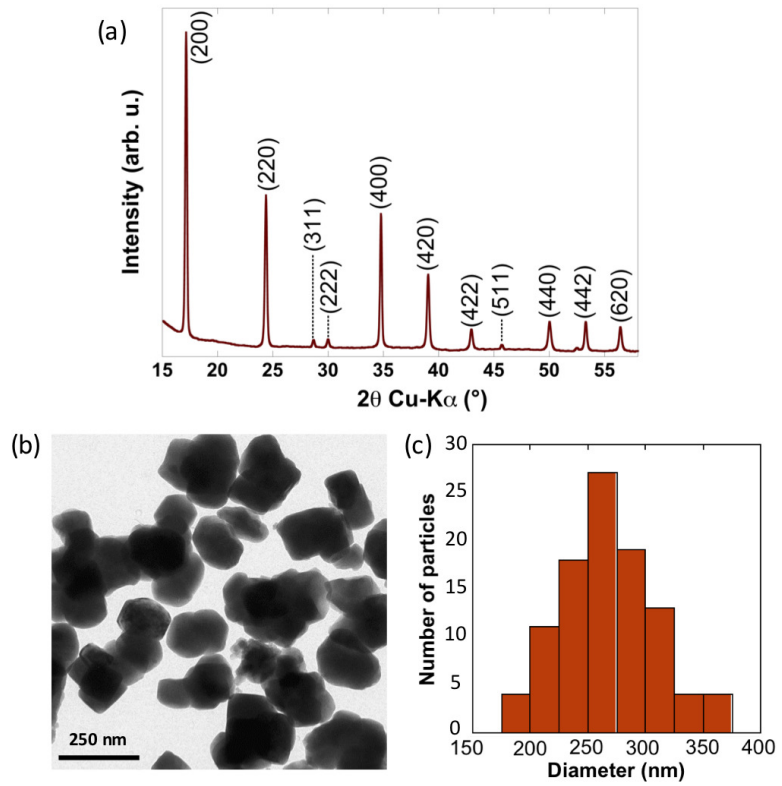

Fig. 1 (a) X-ray diffraction pattern, (b) TEM image and (c) size distribution of CoFe.

$\mathrm{Co}(\mathrm{Co} 75) \mathrm{Fe}-\mathrm{Ox} . \quad \mathrm{Co}_{3} \mathrm{O}_{4}$ was also measured as a reference; we used the commercial product from Alfa Aesar. The spectra were recorded in the transmission mode on the ROCK beamline ${ }^{50}$ at SOLEIL (Gif-sur-Yvette, France) using a Si(111) Quick-EXAFS monochromator. Spectra were recorded in a quick-scan mode from $6900 \mathrm{eV}$ up to $8800 \mathrm{eV}$, allowing both edges to be recorded in a row to minimize experimental artefacts. Measurements were performed on pellets at room temperature. No radiation damage was observed.The spectra were energy-calibrated and normalized following the measurements.

\section{Results and discussion}

\subsection{Characterization of $\mathrm{CoFe}$}

CoFe was characterized by XRD, TEM and elemental analyses. The exact chemical formula of $\mathrm{CoFe}$ is $\mathrm{K}_{0.1} \mathrm{Co}_{4}\left[\mathrm{Fe}(\mathrm{CN})_{6}\right]_{2.7} \bullet 19 \mathrm{H}_{2} \mathrm{O}$ (Table [1]. The peaks of the diffraction pattern (Fig. 1 1 $\mathrm{a}$ ) can be indexed for the face-centeredcubic structure characteristic of PBA,, 15152 with a cell parameter of $10.31 \pm 0.02 \AA$. TEM images (Fig. 1 1 ) show particles with a size distribution (Fig. 11) ranging from 200 to $360 \mathrm{~nm}$ and centered around $250 \mathrm{~nm}$.

Table 1 Elemental analysis results and proposed formula for CoFe.

\begin{tabular}{lllllll}
\hline & $\mathrm{Fe}$ & $\mathrm{Co}$ & $\mathrm{C}$ & $\mathrm{N}$ & $\mathrm{H}$ & $\mathrm{K}$ \\
\hline Experimental (\%) & 12.27 & 19.38 & 16.89 & 19.56 & 3.10 & 0.33 \\
Calculated (\%) & 13.10 & 20.48 & 16.89 & 19.70 & 3.28 & 0.34 \\
Formula & \multicolumn{6}{c}{$\mathrm{K}_{0.1} \mathrm{Co}_{4}\left[\mathrm{Fe}(\mathrm{CN})_{6}\right]_{2.7} \bullet 19 \mathrm{H}_{2} \mathrm{O}$} \\
\hline
\end{tabular}

\subsection{Characterization of CoFe-Ox}

CoFe-Ox (obtained after heating at $900^{\circ} \mathrm{C}$ during $2 \mathrm{~h}$ ) was characterized by XRD and TEM, and the main results are presented in Fig. 2 . (a)

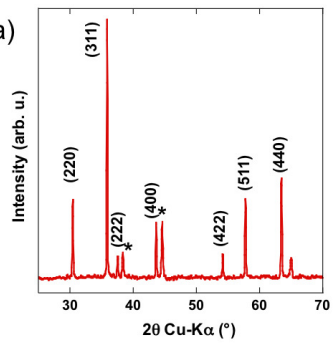

(b)
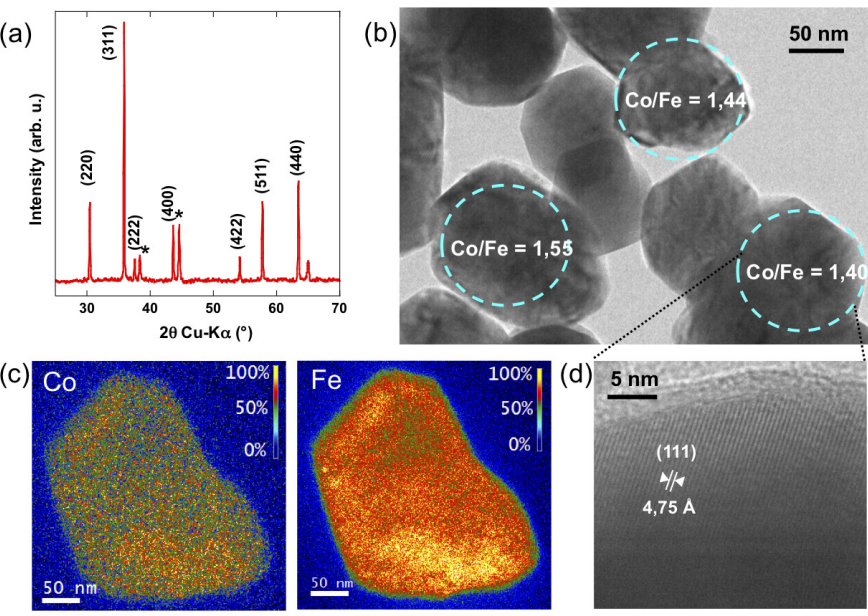

Fig. 2 Characterization of CoFe-Ox by (a) X-ray diffraction pattern, (b) TEM image (with Co:Fe ratio determined by EDX analyses indicated for some particles), (c) Co and Fe $\mathrm{M}_{1}$-edge EFTEM images, and (d) HRTEM image of a particle showing the (111) reticular planes. On the XRD pattern, the peaks marked with an asterisk arise from the aluminum sample holder.

The diffraction pattern of CoFe-Ox is presented Fig. $2 \mathrm{a}$. Only sharp single peaks are observed, which indicates the presence of a single phase. They can be indexed by considering a spinel-type structure, with a cell parameter of $8.29 \pm 0.02 \AA$. This value is intermediate between the cell parameters of $\mathrm{Co}_{3} \mathrm{O}_{4}(\mathrm{a}=$ $8.08 \pm 0.02 \AA)^{53}$ and $\mathrm{CoFe}_{2} \mathrm{O}_{4}(\mathrm{a}=8.38 \pm 0.01 \AA$ 罗, 12 and consistent with the cell parameter $\mathrm{a}=8.24 \AA$ of $\mathrm{Co}_{2} \mathrm{FeO}_{4} \cdot 1216$

The size and shape of the particles were determined from TEM images (Fig. 2p). All particles are in the $100-350 \mathrm{~nm}$ size range. They also all have a Co:Fe ratio of $1.5 \pm 0.2$ (Fig. $2 \mathrm{p}$ ) as determined by EDX analyses; this is perfectly consistent with the Co:Fe initial ratio in $\mathrm{CoFe}$, where $\mathrm{Co}: \mathrm{Fe}=4: 2.7=1.48$. Co and $\mathrm{Fe}$ $\mathrm{M}_{1}$-edge Energy-filtered TEM (EFTEM) images also demonstrated that the $\mathrm{Co}$ and $\mathrm{Fe}$ ions are homogeneously distributed in the particle (Fig. 2k). High-resolution TEM enabled to give an image of the (111) reticular planes, which shows that the particles are single-cristalline. In addition, an inter-reticular distance $\left(\mathrm{d}_{111}\right)$ of $4.75 \AA$ could be calculated from the HR-TEM image, which is consistent with the one from XRD (4.79 $\mathrm{A})$.

Given the spinel-type structure determined by XRD, CoFe$\mathrm{Ox}$ has a $\mathrm{Co}_{x} \mathrm{Fe}_{y} \mathrm{O}_{4}$ formula, where $x+y=3$. Therefore, as the Co:Fe ratio determined by EDX analyses is of 1.5, the proposed formula for CoFe-Ox is $\mathrm{Co}_{1.8} \mathrm{Fe}_{1.2} \mathrm{O}_{4}$ (the absence of $\mathrm{K}$ traces was checked by TEM-EDX). This is fully consistent with previous results on the calcination of PBA into oxide, where the $\mathrm{Fe}_{1.8} \mathrm{Co}_{1.2} \mathrm{O}_{4}$ oxide was obtained from the $\mathrm{Fe}_{3}\left[\mathrm{Co}(\mathrm{CN})_{6}\right]_{2}$ PBA.429

\subsection{Monitoring of the PBA-to-oxide calcination by TDA/TGA} The thermodifferential and gravimetric analyses (TDA and TGA) of CoFe are presented in Fig. 3 Several temperature ranges can be identified.

First, up to $\sim 130^{\circ} \mathrm{C}$ (point A), a mass loss of $29 \%$ is observed, associated with a weak endothermic peak. It can be ascribed to the elimination of water molecules (both zeolitic and structural 


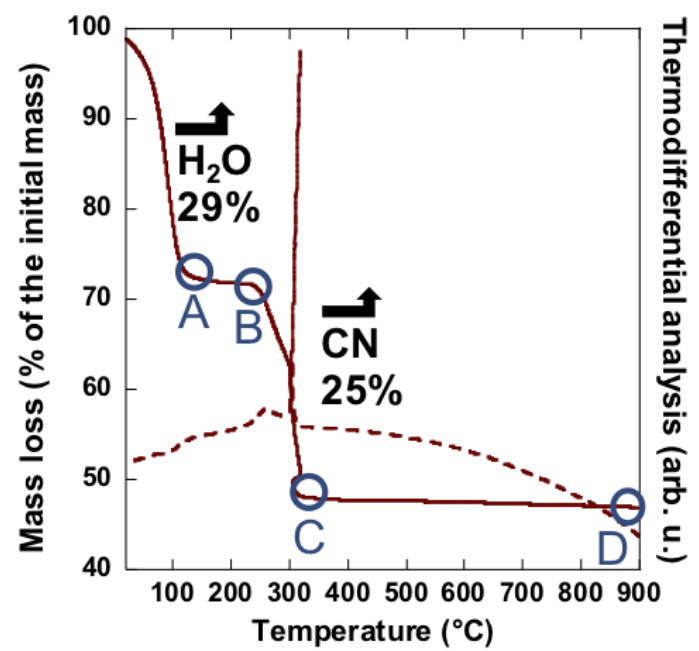

Fig. 3 TDA/TGA pattern recorded for CoFe with a heating rate of $5^{\circ} \mathrm{C} \cdot \mathrm{min}^{-1}$ in air. The continuous line is the mass and the dashed line the thermodifferential analysis.

ones), since this mass difference correponds to the total mass of the 19 water molecules initially present in CoFe.

A plateau in the mass loss is then observed between $130^{\circ} \mathrm{C}$ and $230^{\circ} \mathrm{C}$ (from point A to B in Fig. 3). Over this temperature range, the chemical formula of the compound can be given as $\mathrm{K}_{0.1} \mathrm{Co}_{4}\left[\mathrm{Fe}(\mathrm{CN})_{6}\right]_{2.7}$. The first coordination shell of the Fe ions remains unchanged but, as already observed in the calcination of CoCo, $\frac{54}{5}$ the average coordination number of the Co cations is now 4 since the two water molecules, which were part of their first coordination shell, are now eliminated.

Between $230^{\circ} \mathrm{C}$ and $315^{\circ} \mathrm{C}$ (from point B to C in Fig. 3), two successive mass losses are observed. The first one occurs between $230^{\circ} \mathrm{C}$ and $295^{\circ} \mathrm{C}$ and is accompanied by a small exothermic peak at $260^{\circ} \mathrm{C}$. The second one between $295^{\circ} \mathrm{C}$ and $315^{\circ} \mathrm{C}$ is accompanied by a very intense exothermic peak at $318^{\circ} \mathrm{C}$, which is 20 times more intense than the one at $260^{\circ} \mathrm{C}$. The mass loss and thus the composition of the compound then stabilize up to $900^{\circ} \mathrm{C}$. This represents a cumulated mass loss of $25 \%$ between $230^{\circ} \mathrm{C}$ and $900^{\circ} \mathrm{C}$, which corresponds to the complete decomposition of the cyanide bridges and their replacement by oxygen ligands. The existence of two mass losses can be explained by the presence of two kinds of Co-NC-Fe linkages in CoFe: the $\mathrm{Co}^{\mathrm{II}}-\mathrm{NC}-\mathrm{Fe}^{\mathrm{III}}$ linkages forming the as-synthesized compound and the $\mathrm{Co}^{\mathrm{III}}-\mathrm{NC}-\mathrm{Fe}^{\mathrm{II}}$ linkages resulting from a thermally-induced charge-transfer evidenced by infra-red spectroscopy (ESI $1 \dagger$ ). The Co-N bond being stronger in the $\mathrm{Co}^{\mathrm{III}}-\mathrm{NC}-\mathrm{Fe}^{\mathrm{II}}$ linkages, we propose to assign the most exothermic transformation at higher temperature to the formation of the metal-oxygen bond formation in these particular linkages.

This TGA analysis demonstrates that $54 \%$ of the total mass is lost during the whole process: $29 \%$ because of the elimination of water molecules and $25 \%$ because of the decomposition of the cyanide bridges. If we suppose (i) that all the Co and Fe ions of the PBA precursor are part of the final phase and (ii) that the mass losses are due only to the loss of water molecules and to the re- placement of the $\mathrm{CN}$ ligands by $\mathrm{O}$ ligands, the derived formula of CoFe-Ox is $\mathrm{Co}_{4} \mathrm{Fe}_{2.7} \mathrm{O}_{8.9}$, which can be rewritten as $\mathrm{Co}_{1.8} \mathrm{Fe}_{1.2} \mathrm{O}_{4}$. These results from TGA are thus fully consistent with those from EDX spectroscopy.

To summarize, the process that can be drawn from TDA/TGA is a two-steps transformation : first the elimination of water molecules and then the cyanide decomposition. This 2-step mass loss was already observed for the calcination of other PBA into oxide. 4/27/33/37 So the PBA-to-oxide transformation for the particular case of CoFe can be described by

$\mathrm{Co}_{4}\left[\mathrm{Fe}(\mathrm{CN})_{6}\right]_{2.7} \bullet 19 \mathrm{H}_{2} \mathrm{O} \rightarrow \mathrm{Co}_{4}\left[\mathrm{Fe}(\mathrm{CN})_{6}\right]_{2.7} \rightarrow \mathrm{Co}_{4} \mathrm{Fe}_{2.7} \mathrm{O}_{8.9}$.

\subsection{The transformation process of CoFe}

A calcination of $\mathrm{CoFe}$ during $2 \mathrm{~h}$ in air at $900^{\circ} \mathrm{C}$ thus enables to get a single $\mathrm{Co}_{1.8} \mathrm{Fe}_{1.2} \mathrm{O}_{4}$ spinel phase with a cell parameter of $8.29 \pm 0.02 \AA$, particle sizes ranging from $100 \mathrm{~nm}$ to $350 \mathrm{~nm}$, an homogeneous composition of the particles and an homogeneous repartition of the transition metals inside each particle. To better understand the mechanism of this PBA-to-oxide transformation, the room temperature XRD patterns of CoFe after thermal treatment at variable temperatures were recorded; the most significant temperatures are displayed on Fig. 4, and the XRD patterns for all temperatures are given in ESI $2 \dagger$. After the complete decomposition of the cyanide bridge of $\mathrm{CoFe}$ around $250^{\circ} \mathrm{C}$ (Fig. 3), a continuous evolution of the XRD patterns with temperature is observed (Fig. 4). The most striking feature is the peak splitting at $700^{\circ} \mathrm{C}$, which indicates a phase separation into two phases present in approximately the same quantity (Fig. 4a,b), followed by the formation of a single phase (Fig. 4p) if the calcination is continued up to $900^{\circ} \mathrm{C}$.

The XRD pattern at $300^{\circ} \mathrm{C}$ (Fig. 4 ) displays broad peaks, that can already be indexed for a spinel structure with a unit-cell parameter of $8.22 \AA$. The TEM images indicate that the particle size distribution is relatively narrow and centred around $15 \mathrm{~nm}$. This size is significantly smaller than the size expected for a singleparticle to single-particle transformation. Therefore, the cyanide decomposition is accompanied by the fragmentation of the initial PBA particles. At $500^{\circ} \mathrm{C}$ (Fig. 4 ), a shoulder can be seen for peaks (311), (400), (511) and (440), which suggests the beginning of a phase separation. In particular, two features can be clearly identified for peak (311) (Fig. 4 a-inset) : the most intense one is centered at $36.2^{\circ} 2 \theta$ and the less intense shoulder at $35.5^{\circ} 2 \theta$. We can therefore conclude that at $500^{\circ} \mathrm{C}$, two phases with a different cell parameter exist. The phase with the lowest unit-cell parameter (i.e. at $36.2^{\circ} 2 \theta$ ) is called Phase 1 and the other one Phase 2. This phase separation continues up to $700^{\circ} \mathrm{C}$, as indicated by the more pronounced splitting of the diffraction peaks; Phase 1 remains the major phase, but its unit-cell parameter decreases.

At $700^{\circ} \mathrm{C}$, all the diffraction peaks are now well separated. The comparable intensity of the peaks corresponding to the two phases expresses a similar quantity of the two phases in the sample. For Phase 1, the unit cell parameter of $8.19 \pm 0.02 \AA$ is larger than for the direct spinel $\mathrm{Co}_{3} \mathrm{O}_{4}(8.09 \pm 0.02 \AA$.) but smaller than for the $\mathrm{CoFe}_{2} \mathrm{O}_{4}$ one $(8.38 \pm 0.01 \AA)$. This suggests that Phase 1 


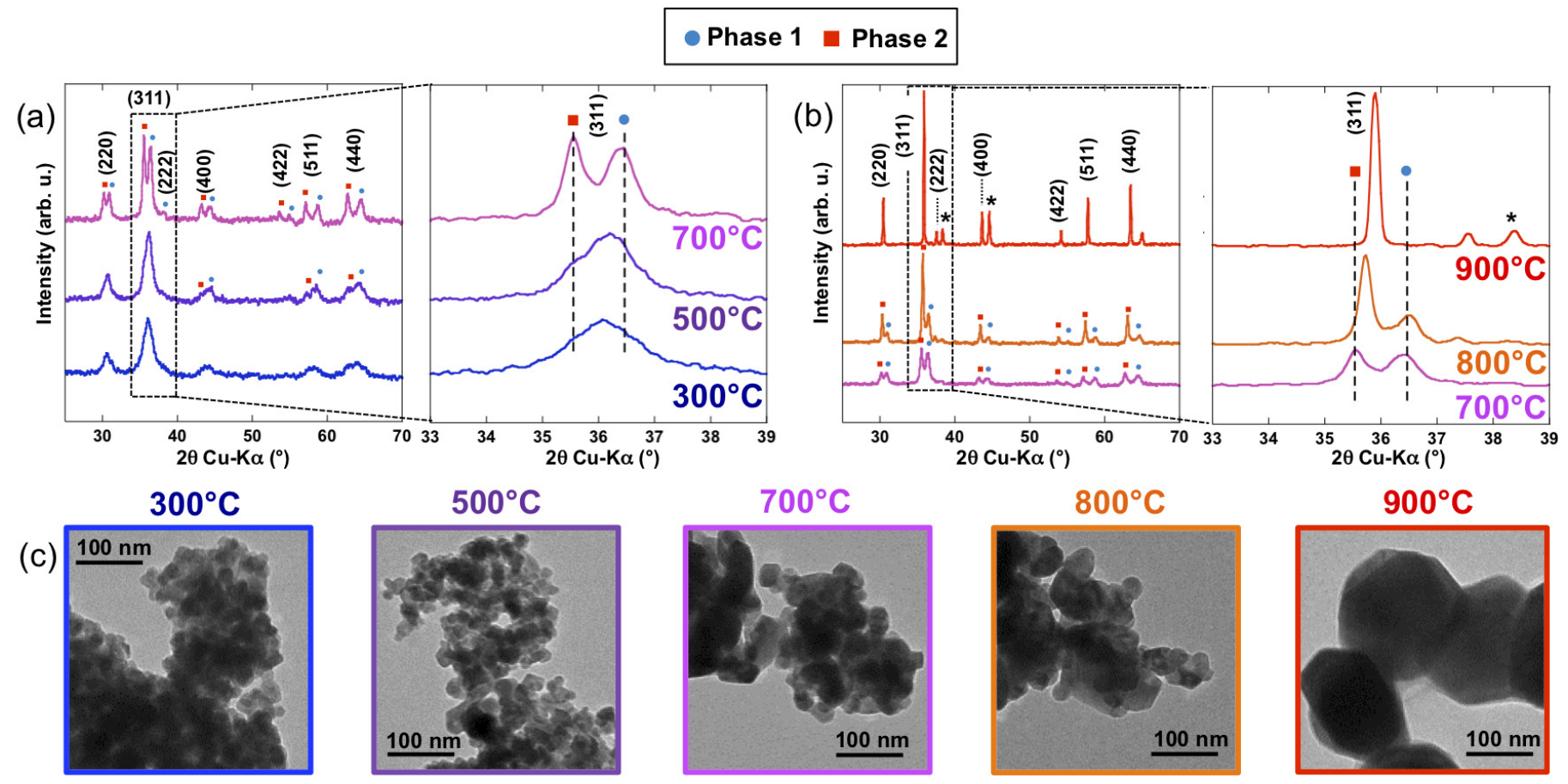

Fig. 4 X-ray diffraction patterns (a,b) and TEM images (c) of CoFe-TT300, CoFe-TT500, CoFe-TT700, CoFe-TT800 and CoFe-Ox (900 $\left.{ }^{\circ} \mathrm{C}\right)$. A zoom of the (311) diffraction peak is presented in the inset of $a$ and $b$. The diffraction peaks marked with an asterisk arise from the aluminum sample holder.

has a spinel structure, with a stoichiometry close to $\mathrm{Co}_{3} \mathrm{O}_{4}$ but with some Fe ions substituted for Co ions. In the case of Phase 2, the cell parameter is found to be $8.37 \pm 0.02 \AA$, which is the value for $\mathrm{CoFe}_{2} \mathrm{O}_{4}$.

Over the $300-700^{\circ} \mathrm{C}$ temperature range, Phase 1 is thus the majority phase from $300^{\circ} \mathrm{C}$ but its lattice parameter varies. Phase 2 already appears at $500^{\circ} \mathrm{C}$, with a well-defined lattice parameter of $8.37 \AA$, which corresponds to the $\mathrm{CoFe}_{2} \mathrm{O}_{4}$ spinel, and an increasing intensity of its diffraction peaks with the increase of temperature. This evolution of the diffraction patterns over this $300-700^{\circ} \mathrm{C}$ range can be explained by the progressive formation of the more stable $\mathrm{CoFe}_{2} \mathrm{O}_{4}$ phase to the detriment of the initial spinel oxide phase. This explains the progressive shortening of its lattice parameter accompanying the increase in $\mathrm{Co} / \mathrm{Fe}$ ratio in Phase 1. Therefore Phase 1 acts as the reservoir for Phase 2 , which develops if the temperature of the thermal treatment is high enough.

If the temperature is still increased up to $750^{\circ} \mathrm{C}$ and $800^{\circ} \mathrm{C}$, an inversion of the relative intensity of the splitted peaks is observed. Phase 2 has become the majority phase. Also, peaks appear sharper at higher temperature. The cell parameter of Phase 1 is $8.16 \pm 0.02 \AA$ at $750^{\circ} \mathrm{C}$, which is smaller than at $700^{\circ} \mathrm{C}$, and remains stable at $800^{\circ} \mathrm{C}$. However, in the case of Phase 2, the cell parameter continuously decreases from $8.37 \pm 0.02 \AA$ at $700^{\circ} \mathrm{C}$ down to $8.36 \pm 0.02 \AA$ at $750^{\circ} \mathrm{C}$ and $8.33 \pm 0.02 \AA$ at $800^{\circ} \mathrm{C}$. At $850^{\circ} \mathrm{C}$, the diffraction pattern display well-defined single peaks: Phase 1 and Phase 2 have merged in a single phase. A small shoulder is still visible at the feet of peak (311) but completely disappears after heating at $900^{\circ} \mathrm{C}$, temperature at which the peaks are sharp and symmetric. The position of peak (311) is also stable at $35.9^{\circ} 2 \theta$ : the unit cell parameter of this final single phase is $8.29 \pm 0.02 \AA$, which is an intermediate value between those of the $\mathrm{CoFe}_{2} \mathrm{O}_{4}$ and $\mathrm{Co}_{3} \mathrm{O}_{4}$ phases. The grain size also increases up to $900^{\circ} \mathrm{C}$, as visible on the TEM images (Fig. 4k), which shows a sintering effect with the increasing temperature.

To summarize, two key temperatures can be identified in the transformation of CoFe to CoFe-Ox: $700^{\circ} \mathrm{C}$, at which the behavior of the two phases switches, and $900^{\circ} \mathrm{C}$, at which the single CoFe-Ox phase is formed. Below $700^{\circ} \mathrm{C}$, Phase 2 is the well defined $\mathrm{CoFe}_{2} \mathrm{O}_{4} \mathrm{Fe}$-rich spinel oxide. Assuming that all the ions initially present in CoFe are also in CoFe-Ox, Phase 2 is thus produced from ions present in Phase 1, which acts as an ion reservoir. Above $700{ }^{\circ} \mathrm{C}$ and as temperature increases, Phase 1 is progressively incorporated into Phase 2, whose unit-cell parameter and so chemical composition now varies till the homogeneous $\mathrm{Co}_{1.8} \mathrm{Fe}_{1.2} \mathrm{O}_{4}$ particles at $900^{\circ} \mathrm{C}$. These observations can be compared to the case of the $\mathrm{Co}_{2} \mathrm{FeO}_{4}$ spinel, whose formation as a single phase was observed only for a calcination temperature of $900^{\circ} \mathrm{C} .12\left[16\right.$ Ferreira and co-workers ${ }^{12}$ used a low-temperature co-precipitation method followed by annealing at various temperatures between $300^{\circ} \mathrm{C}$ and $1000^{\circ} \mathrm{C}$ to synthesize the two $\mathrm{Co}_{2} \mathrm{FeO}_{4}$ and $\mathrm{CoFe}_{2} \mathrm{O}_{4}$ spinels. Their detailed structural and morphological characterization showed in the case of $\mathrm{Co}_{2} \mathrm{FeO}_{4}$ the presence of two spinel phases over the $300-800^{\circ} \mathrm{C}$ temperature range, one richer in $\mathrm{Fe}(\mathrm{a}=8.27 \AA)$ and one richer in Co $(\mathrm{a}=8.11 \AA)$. Only the thermal treatment at $900^{\circ} \mathrm{C}$ led to the single $\mathrm{Co}_{2} \mathrm{FeO}_{4}$ phase. Ferreira and co-workers noticed that this narrow temperature range allowing the formation of $\mathrm{Co}_{2} \mathrm{FeO}_{4}$ is consistent with the phase diagram of Co-Fe-O described by Murray and Linnett, which predicts the stability of $\mathrm{Co}_{2} \mathrm{FeO}_{4}$ only around $900^{\circ} \mathrm{C} \cdot{ }^{[55} \mathrm{A}$ later study by Panneer Muthuselvam and Bhowmik also observed this formation of $\mathrm{Co}_{2} \mathrm{FeO}_{4}$ only around $900^{\circ} \mathrm{C}$, despite a different 
synthesis approach. ${ }^{16}$ They mechanically alloyed a mixed powder of stoichiometric amounts of $\mathrm{Fe}_{2} \mathrm{O}_{3}$ and $\mathrm{Co}_{3} \mathrm{O}_{4}$ with a subsequent annealing under different conditions (temperature, time). Their XRD patterns revealed the presence of a single spinel phase only for calcination at $900^{\circ} \mathrm{C}$ and $950^{\circ} \mathrm{C}$. Below $900^{\circ} \mathrm{C}$ and at $1000^{\circ} \mathrm{C}$, two spinel phases can be observed, one richer in Fe with a higher cell parameter and one richer in Co with a lower parameter. At $700^{\circ} \mathrm{C}$, their Fe-rich phase has a cell parameter of $8.37 \AA$, which is identical to Phase 2 in our case. Their Co-rich phase has a cell parameter of $8.13 \AA$, which is slightly lower than our Phase 1 but consistent with the fact that our single phase at $900^{\circ} \mathrm{C}$ is richer in $\mathrm{Fe}\left(\mathrm{Co}_{1.8} \mathrm{Fe}_{1.2} \mathrm{O}_{4}\right)$ than their $\mathrm{Co}_{2} \mathrm{FeO}_{4}$ phase. All these observations indicate that the formation of this particular Co-rich ferrite spinel is not related to the synthesis way but only to the final calcination temperature.

\subsection{Towards a complete control of the oxide stoichiometry}

The calcination at $900^{\circ} \mathrm{C}$ of $\mathrm{CoFe}$ thus leads to the formation of a single spinel phase with an identical Co:Fe ratio than in the PBA precursor. It tends to confirm that the stoichiometry of the oxide is fully controlled by the stoichiometry of the PBA precursor, as observed in the calcination of some other PBAs into oxides. 42933 To strengthen this hypothesis, we prepared PBAs of controlled stoichiometry along the CoFe-CoCo solidsolution. Three intermediate PBA were prepared $(\mathrm{Co}(\mathrm{Co25}) \mathrm{Fe}$, $\mathrm{Co}(\mathrm{Co50}) \mathrm{Fe}$ and $\mathrm{Co}(\mathrm{Co} 75) \mathrm{Fe})$ and calcinated at $900^{\circ} \mathrm{C}$ following the same protocol than for $\mathrm{CoFe}$, leading to the three $\mathrm{Co}(\mathrm{Co} 25) \mathrm{Fe}-\mathrm{Ox}, \mathrm{Co}(\mathrm{Co} 50) \mathrm{Fe}-\mathrm{Ox}$ and $\mathrm{Co}(\mathrm{Co} 75) \mathrm{Fe}-\mathrm{Ox}$ oxides.

The calcinated PBAs were first investigated by TEM and EDX spectroscopy, in order to determine the Co:Fe ratio. The three oxides consist in homogeneous particles, and the experimental Co:Fe ratio is given in Table 2. First, the EDX analyses showed that for a given stoichiometry, the chemical composition is the same for all the particles, as already observed for CoFe-Ox. Then, the average Co:Fe ratio measured by EDX for a given composition is really close to the one expected from the formula of the PBA precursor. This is an unambiguous confirmation that the stoichiometry of the oxide can be fully controlled by the PBA stoichiometry, even for intermediate compositions.

The XRD patterns were then used to determine the cell parameter of both the PBAs and the oxides; they are given in Table 2 and their variations along the CoFe-CoCo and the $\mathrm{Co}_{1.8} \mathrm{Fe}_{1.2} \mathrm{O}_{4}$ $\mathrm{Co}_{3} \mathrm{O}_{4}$ solid-solutions are diplayed in Fig. 5. A linear relationship between the Co content in the $\left[\mathrm{M}(\mathrm{CN})_{6}\right]$ unit of the PBA and the cell parameter of both the PBAs and the oxides can be observed, which indicates that the changes in the PBA precursor directly impact the oxide. This is also another indication that the stoichiometry of the oxide is controlled by the one of the PBA; otherwise the linear relationship would have been lost for the oxide. It has to be noted that the unit-cell parameter of $\mathbf{C o ( C o 2 5 ) F e , ~ w h o s e ~}$ formula is $\mathrm{Co}_{2.1} \mathrm{Fe}_{0.9} \mathrm{O}_{4}$, is identical (8.24 $\AA$ ) to the value found in literature for the $\mathrm{Co}_{2.03} \mathrm{Fe}_{0.97} \mathrm{O}_{4}$ and $\mathrm{Co}_{2.04} \mathrm{Fe}_{0.96} \mathrm{O}_{4}$ spinels. 12 Our new route for the synthesis of mixed oxides from PBAs is thus very reliable since, for particular stoichiometries that can be obtained via other routes, the final phase of oxide is identical.

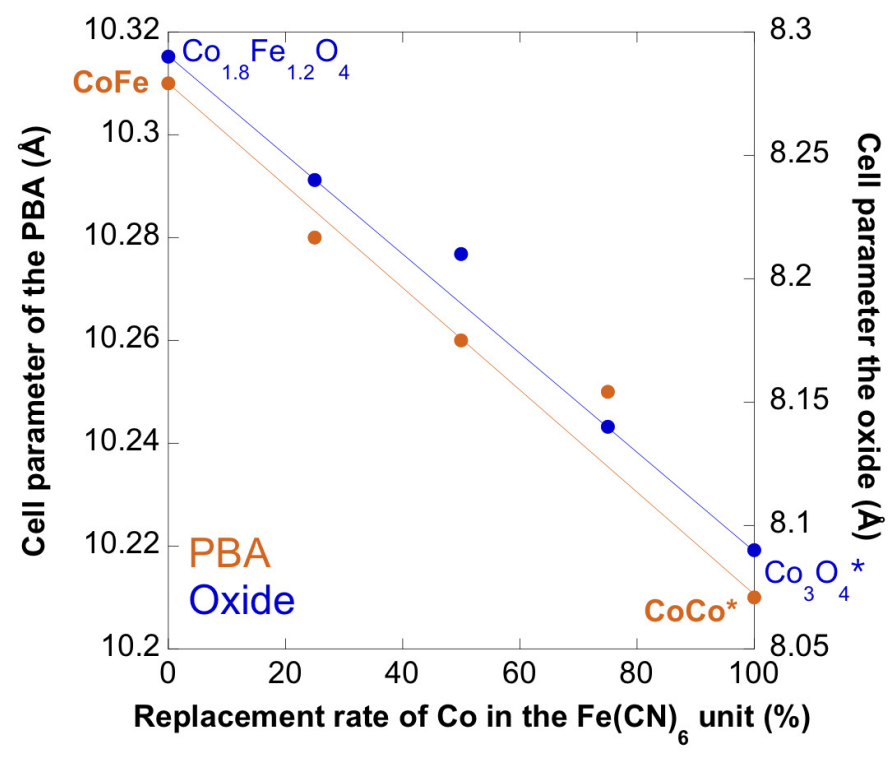

Fig. 5 Evolution of the cell parameter of the $\mathrm{CoFe}\left(\mathrm{Co}_{4}\left[\mathrm{Fe}(\mathrm{CN})_{6}\right]_{2.7}\right)-$ CoCo $\left(\mathrm{Co}_{4}\left[\mathrm{Co}(\mathrm{CN})_{6}\right]_{2.7}\right)$ PBA solid-solution (orange points) and the corresponding $\mathrm{CoFe}-\mathrm{Ox}\left(\mathrm{Co}_{1.8} \mathrm{Fe}_{1.2} \mathrm{O}_{4}\right)-\mathrm{Co}_{3} \mathrm{O}_{4}$ oxide solid-solution (blue points). The values for $\mathrm{CoCo}$ and $\mathrm{Co}_{3} \mathrm{O}_{4}\left(^{*}\right)$ are taken from Ref. 35.

Fe and Co K-edges X-ray absorption spectra of the four compounds (CoFe-Ox, Co(Co25)Fe-Ox, Co(Co50)Fe-Ox and Co(Co75)Fe-Ox) are displayed in Fig. 6a and b. At both edges, the shape and energy of the spectral features are close for the four compounds, which indicates a comparable average speciation of the Co and Fe ions among the four oxides. But the most interesting feature is that the maximum of the white line at both edges linearly shifts towards higher energy when the content in Co inserted in the $\left[\mathrm{M}(\mathrm{CN})_{6}\right]$ units increases (Fig. 66); this linear relationship also stands if the extreme compound of the solidsolution $\left(\mathrm{Co}_{3} \mathrm{O}_{4}\right)$ is included into the set of data. This clearly confirms the continuous displacement along the solid solution from CoFe-Ox to $\mathrm{Co}_{3} \mathrm{O}_{4}$.

The main interest in the control of the stoichiometry is the control of the property. We thus performed SQUID magnetometry measurements to investigate the magnetic property at roomtemperature of the four oxides; the magnetization curve as a function of the magnetic field are displayed in Fig. 7. The magnetic properties evolve progressively along the series as an increasing amount of Co ions replaces Fe ones, in agreement with a homogeneous repartition of the $\mathrm{Co}$ and $\mathrm{Fe}$ ions within the samples without phase separation. The Co spinel oxide $\left(\mathrm{Co}_{3} \mathrm{O}_{4}\right)$ is antiferromagnetic below a Néel temperature $\left(\mathrm{T}_{\mathrm{N}}\right)$ of $35 \pm 5 \mathrm{~K}$ and exhibits a paramagnetic behavior above $\mathrm{T}_{\mathrm{N}} \cdot \frac{5657}{5}$ In this compound, the octahedral and tetrahedral sites contain $\mathrm{Co}^{\mathrm{III}}(\mathrm{LS})$ and $\mathrm{Co}^{\mathrm{II}}(\mathrm{HS})$ ions respectively. Thus, the samples with the higher Co ions content, Co(Co75)Fe-Ox and Co(Co50)Fe-Ox, exhibit a paramagnetic behavior at $300 \mathrm{~K}$ like the $\mathrm{Co}$ spinel oxide $\mathrm{Co}_{3} \mathrm{O}_{4}$. The magnetization at $4 \mathrm{~T}$, slightly higher in $\mathrm{Co}(\mathrm{Co50}) \mathrm{Fe}-\mathrm{Ox}\left(0.15 \mu_{B}\right)$ than in $\mathrm{Co}(\mathrm{Co} 75)\left(0.05 \mu_{B}\right)$ can be explained by an increasing replacement of the $\mathrm{Co}^{\mathrm{III}}(\mathrm{LS})(\mathrm{S}=0)$ and/or $\mathrm{Co}^{\mathrm{II}}(\mathrm{HS})(\mathrm{S}=3 / 2)$ ions by $\mathrm{Fe}^{\mathrm{III}}(\mathrm{HS})(\mathrm{S}=5 / 2)$ and/or $\mathrm{Fe}^{\mathrm{II}}(\mathrm{HS})(\mathrm{S}=2)$ ones. As 
Table 2 Cell parameter and formula of the PBA and oxides along the $\mathrm{CoFe}-\mathrm{Co}_{3} \mathrm{O}_{4}$ solid-solution. The value for the end member are reminded.

\begin{tabular}{c||cc||cc|cc}
\hline $\begin{array}{c}\text { Replacement rate } \\
\text { of Co in the } \\
\text { Fe }(\mathrm{CN})_{6} \text { unit }\end{array}$ & Formula & \multicolumn{2}{c}{ PBA } & $\begin{array}{c}\text { Unit cell } \\
\text { parameter }\end{array}$ & Formula & \multicolumn{2}{c}{$\begin{array}{c}\text { Oxide } \\
\text { parameter }\end{array}$} & \multicolumn{2}{c}{$\begin{array}{c}\text { Co:Fe ratio } \\
\text { from EDX }\end{array}$} \\
\hline $0 \%$ & $\mathrm{Co}_{4}\left[\left(\mathrm{Fe}(\mathrm{CN})_{6}\right]_{2.7}\right.$ & $10.31 \AA$ & $\mathrm{Co}_{1.8} \mathrm{Fe}_{1.2} \mathrm{O}_{4}$ & $8.29 \AA$ & 1.4 & 1.5 \\
$25 \%$ & $\mathrm{Co}_{4}\left[\left(\mathrm{Fe}_{0.75} \mathrm{Co}_{0.25}\right)(\mathrm{CN})_{6}\right]_{2.7}$ & $10.28 \AA$ & $\mathrm{Co}_{2.1} \mathrm{Fe}_{0.9} \mathrm{O}_{4}$ & $8.24 \AA$ & 2.1 & 2.3 \\
$50 \%$ & $\mathrm{Co}_{4}\left[\left(\mathrm{Fe}_{0.50} \mathrm{Co}_{0.50}\right)(\mathrm{CN})_{6}\right]_{2.7}$ & $10.26 \AA$ & $\mathrm{Co}_{2.4} \mathrm{Fe}_{0.6} \mathrm{O}_{4}$ & $8.21 \AA$ & 3.7 & 4.0 \\
$75 \%$ & $\mathrm{Co}_{4}\left[\left(\mathrm{Fe}_{0.25} \mathrm{Co}_{0.75}\right)(\mathrm{CN})_{6}\right]_{2.7}$ & $10.24 \AA$ & $\mathrm{Co}_{2.7} \mathrm{Fe}_{0.3} \mathrm{O}_{4}$ & $8.14 \AA$ & 8.0 & 9.0 \\
$100 \%$ & $\mathrm{Co}_{4}\left[\mathrm{Co}(\mathrm{CN})_{6}\right]_{2.7}$ & $10.21 \AA$ & $\mathrm{Co}_{3} \mathrm{O}_{4}$ & $8.09 \AA$ & $/$ & $/$ \\
\hline
\end{tabular}
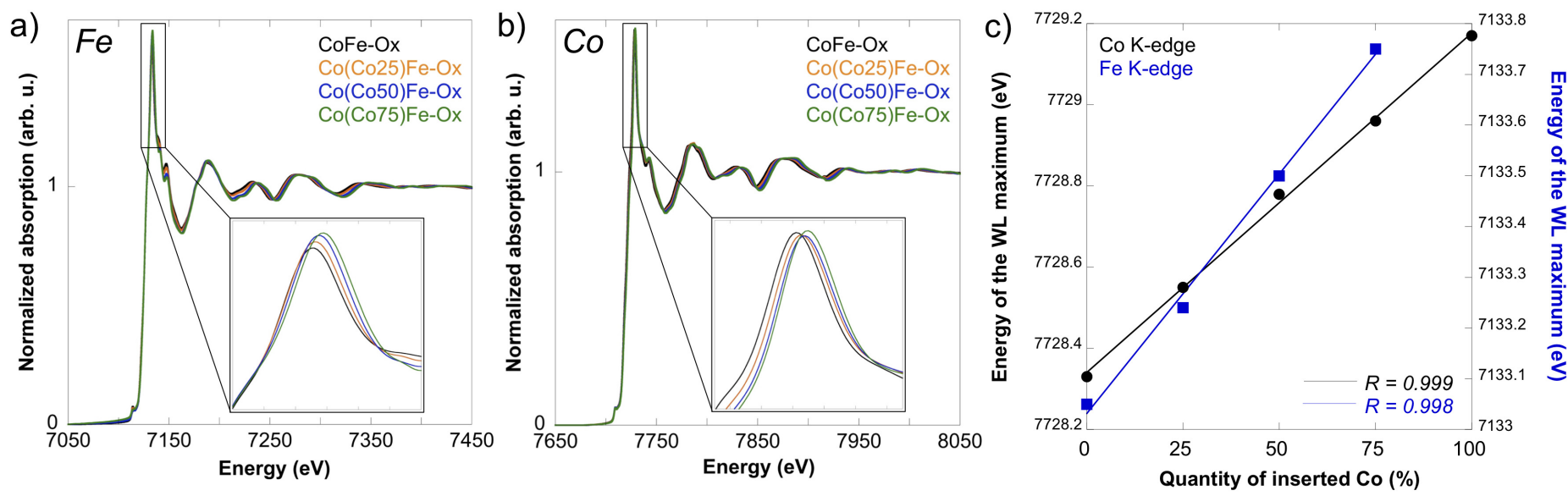

Fig. 6 (a) Fe and (b) Co K-edges X-ray absorption spectra of CoFe-Ox, Co(Co25)Fe-Ox, Co(Co50)Fe-Ox and Co(Co75)Fe-Ox, with a zoom on the maximum of the white line. (c) Evolution of the energy of the white line maximum in the oxides along the $\mathrm{CoFe}^{-} \mathrm{Co}_{3} \mathrm{O}_{4}$ solid-solution; the dots represent the experimental values and the line the corresponding linear regression.

the amount of Fe ions still increases, an hysteresis loop appears revealing a room-temperature magnet behavior for $\mathbf{C o ( C o 2 5 ) F e - ~}$ Ox and CoFe-Ox. The increase in saturation magnetization and in coercive field from one compound to the other can again be explained by the progressive replacement of Co ions by Fe ones.

To summarize, all these results on the calcination of CoFe into CoFe-Ox and on the three intermediate compositions along the $\mathrm{CoFe}-\mathrm{Co}_{3} \mathrm{O}_{4}$ solid-solution clearly demonstrate that the stoichiometry of the PBA precursor fully controls the stoichiometry of the mixed oxide.

\subsection{Transposition of the process at the nanoscale}

The results presented in the previous sections demonstrate the successful transformation of the PBA into a mixed oxide with controlled stoichiometry. However, one of the main interest of a functional material for application is the possibility to shape it at a nanoscale, as shown by the several investigations on the synthesis process and properties of ferrite nanoparticles. $\frac{3|5| 18 \mid 58,63}{63}$ Therefore we tried to transpose the transformation of CoFe into CoFeOx at the nanoscale by combining the formation of a mixed oxide from a PBA (this work) and the control growth of PBA nanoparticles inside the porosity of a mesoporous silica monolith. Some of our previous works indeed demonstrated that the confinement of CoFe growth inside the pores of a mesoporous silica monolith 35 40/44 48 leads to the formation of nanoparticles whose size is controlled by the size of the pores. We first tested this combined

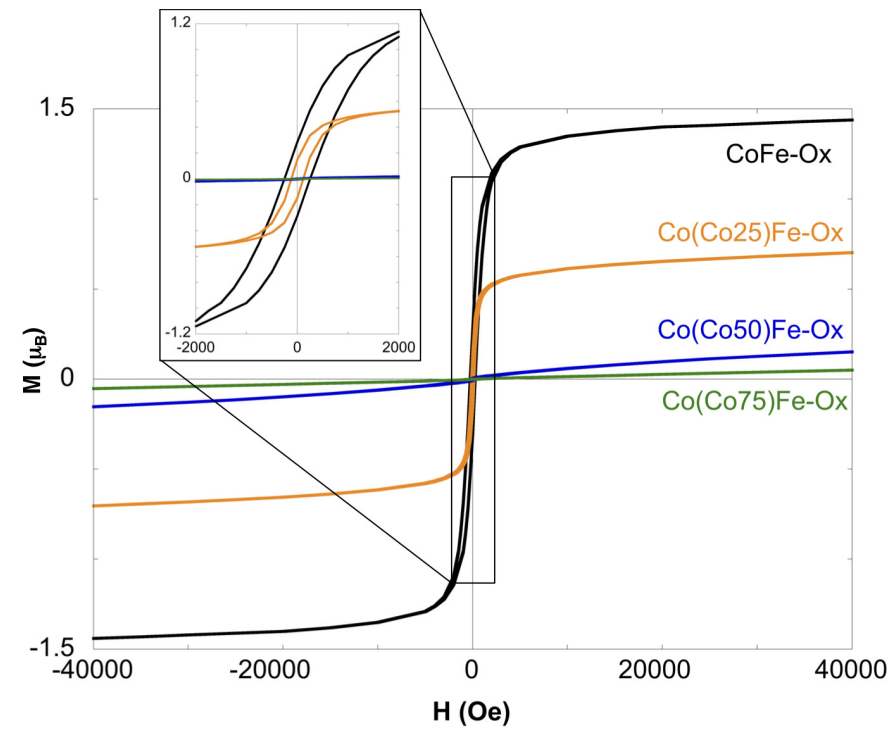

Fig. 7 Evolution of the magnetization as a function of the magnetic field at room temperature for the 4 oxides CoFe-Ox, Co(Co25)Fe-Ox, $\mathrm{Co}(\mathrm{Co50}) \mathrm{Fe}-\mathrm{Ox}$ and $\mathrm{Co}(\mathrm{Co} 75) \mathrm{Fe}-\mathrm{Ox}$. 
approach with the simple case of the calcination of monometallic PBA nanoparticles; we obtained oxide nanoparticles of controlled and monodispersed size, with the expected $\mathrm{Co}_{3} \mathrm{O}_{4}$ spinel structure and composition. ${ }^{35}$ Here we confined CoFe into the $4.5 \mathrm{~nm}$-pores of a mesoporous silica (this new precursor is called NanoCoFe) and then applied the thermal treatment to NanoCoFe, in order to get $5 \mathrm{~nm}$-particles of the $\mathrm{Co}_{1.8} \mathrm{Fe}_{1.2} \mathrm{O}_{4}$ mixed oxide (called NanoCoFe-Ox, as the particles remain in the porosity).

The thermodifferential and thermogravimetric analyses are shown in Fig. 83. As for $\mathbf{C o F e}$, two mass losses are observed. The first one occurs until $115^{\circ} \mathrm{C}$ and corresponds to the elimination of water from both the silica and the PBA structure; $11 \%$ of the total mass is thus lost. Then, a mass loss of $4 \%$ spreads until $310^{\circ} \mathrm{C}$; it is accompanied by a unique exothermic peak at $282^{\circ} \mathrm{C}$, which corresponds to the cyanide bridge decomposition. Above $310^{\circ} \mathrm{C}$, the mass loss slightly continues because of the silica matrix condensation under heating.

The chosen temperature for the thermal treatment of NanoCoFe $\left(700^{\circ} \mathrm{C}\right)$ is a compromise between the temperature required to transform the CoFe into CoFe-Ox and the one that keeps intact the ordered mesoporous structure of the silica. The TEM image of longitudinal section of NanoCoFe-Ox (Fig. 8p) nicely shows the preservation of the silica organization after the thermal treatment, as previously observed for the transformation of a Co monometallic PBA into $\mathrm{Co}_{3} \mathrm{O}_{4} \cdot \sqrt{35}$ Almost all parallel pores of the silica contain spherical particles. The HR-TEM image of one of these particles (Fig. 8) shows the parallel lines corresponding to reticular planes of a single-crystalline particle. The average measured distance between two successive lattice planes $(0.242 \pm$ $0.004 \mathrm{~nm}$ ) of this single-crystal corresponds to an interplanar distance consistent with the (311) $d$-spacing of a CoFe spinel oxide. EDX spectroscopy could be performed on the particles (Fig. 8d), and the Co:Fe ratio is found to be 1.5, as expected from the Co:Fe ratio in NanoCoFe particles and also the CoFe-Ox ones (Fig. 2p). Finally, a statistical analysis of the particle size reveals that the average size is $4.5 \mathrm{~nm}$ with a narrow size distribution (Fig. 8p); it means that the particles fill the entire diameter of the pores, indicating that the particles size is controlled by the pore size.

Therefore, NanoCoFe-Ox can be described as an ordered mesoporous silica monolith containing single-crystalline CoFe spinel nanoparticles within its porosity. Given the Co:Fe ratio of 1.5 as for $\mathbf{C o F e - O x}$, the deduced stoichiometry of the nanoparticles is $\mathrm{Co}_{1.8} \mathrm{Fe}_{1.2} \mathrm{O}_{4}$. The confinement of the PBA particles may thus influence the calcination process, as suggested by the lower calcination temperature for NanoCoFe with respect to $\mathrm{CoFe}$, but it does not prevent the formation of homogeneous single-crystalline nanoparticles. This synthesis route for oxide nanoparticles is compared to the more conventional mixing of nitrate salts in our reference 64 , along a detailed investigation of the magnetic properties of the nanoparticles. A detailed investigation of the impact of confinement and of the synthesis conditions of the confined PBA on the calcination process will be presented in an upcoming publication.

\section{Conclusion}

We presented here the successful synthesis of mixed Co-Fe oxides with a fine control of their stoichiometry through the controlled variation of the Co:Fe ratio in their PBA precursor. The thermal treatment, derived from our previous investigations of the transformation of a Co monometallic PBA into $\mathrm{Co}_{3} \mathrm{O}_{4}, 355$ was optimized thanks to a detailed XRD investigation of the calcination process. In the case of CoFe, we demonstrate here that a single-crystalline single phase can be obtained only around $900^{\circ} \mathrm{C}$ with a 2-phases intermediate step, as observed for the synthesis of $\mathrm{FeCo}_{2} \mathrm{O}_{4}$ by other techniques. $12[16$ The characterization of these intermediate spinel phases and of the kinetics effects is in progress and will bring a deep insight into the calcination mechanism; in particular, in situ Co and Fe K-edges X-ray absorption spectroscopy experiments were recently performed to characterize at the local scale the variation of the $\mathrm{Fe}$ and Co electronic structure and local environment during the calcination process. Also, the versatility of this synthesis route is successfully demonstrated with our present results for mixed oxides and nanoparticles. It has to be noted that we and other groups also successfully extend the use of PBA as precursors to (i) the case of alloys $\frac{34|64| 67}{6 n}$ and (ii) the formation of nanoparticles in other matrices templates such as perforated thin films. 6869

To conclude, our results, combined with literature, definitively confirm that PBA are the most versatile, controllable and reliable precursors for the synthesis of oxides with a controlled stoichiometry and particle size. This offers a unique way to design oxides with targeted properties.

\section{Conflicts of interest}

There are no conflict of interest to declare.

\section{Acknowledgments}

V. Trannoy thanks the Région Ile-de-France C'Nano program (no. GDR2972) for the PhD financial support. MIR spectroscopy analyses were obtained by Kevin Privat during its internship. The XAS experiments on the ROCK beamline were supported by a public grant overseen by the French National Research agency (ANR) as part of the "Investissements d'Avenir" program (reference ANR10-EQPX-45). The authors acknowledge SOLEIL for the provision of synchrotron radiation facilities through proposal 20160306.

\section{Notes and references}

1 E. Casbeer, V. K. Sharma and X.-Z. Li, Separation and Purification Technology, 2012, 87, 1-14.

2 S. Jauhar, J. Kaur, A. Goyal and S. Singhal, RSC Advances, 2016, 6, 97694-97719.

3 K. K. Kefeni, T. A. Msagati and B. B. Mamba, Materials Science and Engineering B, 2017, 215, 37-55.

4 L. Hu, Y. Huang and Q. Chen, Journal of Alloys and Compounds, 2013, 559, 57-63.

5 X. Li, Z. Wang, B. Zhang, A. I. Rykov, M. A. Ahmed and J. Wang, Applied Catalysis B: Environmental, 2016, 181, 788799. 


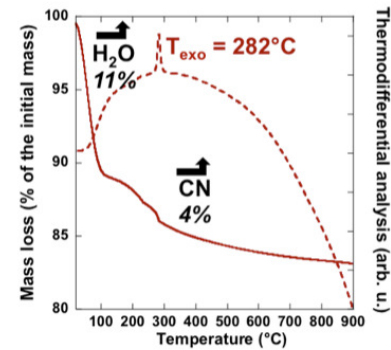

(a)

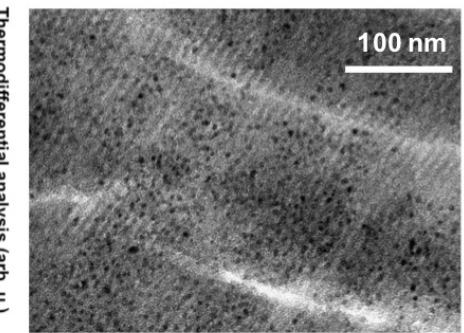

(b)

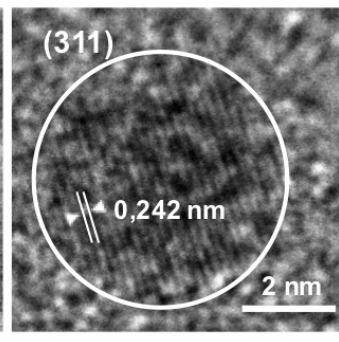

(c)

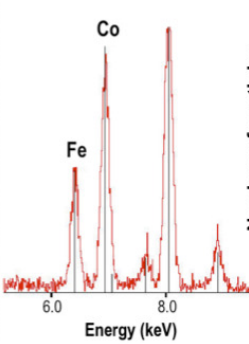

(d)

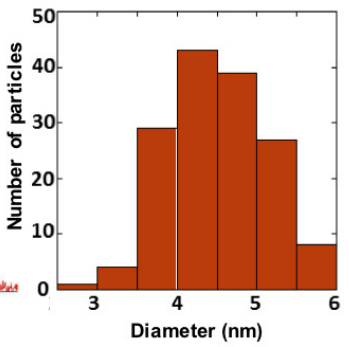

(e)

Fig. 8 (a) TDA/TGA pattern recorded for NanoCoFe with a heating rate of $5^{\circ} \mathrm{C} \cdot \mathrm{min}^{-1}$ in air (the continuous line is the mass and the dashed line the thermodifferential analysis). (b) TEM image of a longitudinal section (prepared by microtomy) of NanoCoFe-Ox, (c) HR-TEM image and the (d) corresponding EDX spectrum of a particle, and (e) histogram of the particle size distribution.

6 M. Lv, X. Guo, Z. Wang, L. Wang, Q. Li and Z. Zhang, RSC Advances, 2016, 6, 27052-27059.

7 D. H. K. Reddy and Y.-S. Yun, Coordination Chemistry Review, 2016, 35, 90-111.

8 A. Šutka and K. A. Gross, Sensors and Actuators B: Chemical, 2016, 222, 95-105.

9 D. H. Taffa, R. Dillert, A. C. Ulpe, K. C. L. Bauerfeind, T. Bredow, D. W. Bahnemann and M. Wark, Sensors and Actuators B: Chemical, 2016, 222, 95-105.

10 J. Zhang, L. Wang, L. Xu, X. Ge, X. Zhao, M. Lai, Z. Liu and W. Chen, Nanoscale, 2015, 7, 720-726.

11 F. Zhao, J. Tian and B. Wang, Materials Letters, 2015, 161, 104-107.

12 T. Ferreira, J. Waerenborgh, M. Mendonca, M. Nunes and F. Costa, Solid State Sciences, 2003, 5, 383-392.

13 Y. Qi, Y. Yang, X. Zhao, X. Liu, P. Wu, F. Zhang and S. Xu, Materials Letters, 2006, 60, 3548-3552.

14 P. Aghav, V. N. Dhage, M. L. Mane, D. Shengule, R. Dorik and K. Jadhav, Physica B, 2011, 406, 4350-4354.

15 A. M. Wahba and M. B. Mohamed, Journal of Magnetism and Magnetic Materials, 2015, 378, 246-252.

16 I. Panneer Muthuselvam and R. N. Bhowmik, Solid State Sciences, 2009, 11, 719-725.

17 A. P. Herrera, L. Polo-Corrales, E. Chavez, J. Cabarcas-Bolivar, O. N. Uwakweh and C. Rinaldi, Journal of Magnetism and Magnetic Materials, 2013, 328, 41-52.

18 M. Houshiar, F. Zebhi, Z. J. Razi, A. Alidoust and Z. Askari, Journal of Magnetism and Magnetic Materials, 2014, 371, 4348.

19 M. G. Naseri, E. B. Saion, H. A. Ahangar, A. H. Shaari and M. Hashim, Journal of Nanomaterials, 2010, 2010, 907686.

20 Y. Qu, H. Yang, N. Yang, Y. Fan, H. Zhu and Z. Guangtian, Particuology, 2010, 8, 207-211.

21 M. Shi, R. Zuo, Y. Xu, Y. Jiang, G. Yu, H. Su and J. Zhong, Journal of Alloys and Compounds, 2012, 512, 165-170.

22 V. Sudheesh, N. Thomas and P. a. S. V. Roona, N. ans Baghya, Ceramics International, 2017, 43, 15002-15009.

23 P. R. Varma, R. S. Manna, B. D., M. R. Varma, K. Suresh and A. Nigam, Journal of Alloys and Compounds, 2008, 453, 298303.
24 J. Wang, T. Deng, Y. Lin, C. Yang and W. Zhan, Journal of Alloys and Compounds, 2008, 450, 532-539.

25 L. Han, X.-Y. Yu and X. W. D. Lou, Advanced Materials, 2016, 28, 4601-4605.

26 X. Hou, G. Zhu, X. Niu, Z. Dai, Z. Yin, Q. Dong, Y. Zhang and X. Dong, Journal of Alloys and Compounds, 2017, 729, 518-525.

27 X. Li, L. Yuan, J. Wang, L. Jiang, A. I. Rykov, D. L. Nagy, C. Bogdán, M. A. Ahmed, G. Zhu, Kaiyue adnd Sun and W. Yang, Nanoscale, 2016, 8, 2333-2342.

28 S. Rohilla, B. Lal, S. Sunder, P. Aghamkar, S. Kumar and A. Aggarwal, Acta Physica Polonica A, 2010, 118, 696-700.

29 M. B. Zakaria, M. Hu, M. Imura, R. R. Salunkhe, N. Umezawa, H. Hamoudi, A. A. Belik and Y. Yamauchi, Chemistry - A European Journal, 2014, 20, 17375-17384.

30 M. B. Zakaria, M. Hu, N. Hayashi, Y. Tsujimoto, S. Ishihara, M. Imura, N. Suzuki, Y.-Y. Huang, Y. Sakka, K. Ariga, K. C.-W. Wu and Y. Yamauchi, European Journal of Inorganic Chemistry, 2014, 2014, 1137-1141.

31 M. B. Zakaria, M. Hu, M. Pramanik, C. Li, J. Tang, A. Aldalbahi, S. M. Alshehri, V. Malgraas and Y. Yamauchi, Chemistry - An Asian Journal, 2015, 10, 1541-1545.

32 M. B. Zakaria, M. S. A. Hossain, M. J. A. Shiddiky, M. Shahabuddin, E. Yanmaz, J. H. Kim, A. A. Belik, Y. Ide, M. Hu, S. Tominaka and Y. Yamauchi, Chemistry - A European Journal, 2016, 22, 15042-15048.

33 M. B. Zakaria, C. Li, M. Pramanik, Y. Tsujimoto, M. Hu, V. Malgras, S. Tominaka and Y. Yamauchi, Journal of Materials Chemistry A, 2016, 4, 9266-9274.

34 M. B. Zakaria and T. Chikyow, Coordination Chemistry Review, 2017, 352, 328-345.

35 V. Trannoy, E. Delahaye, G. Fornasieri, P. Beaunier and A. Bleuzen, Comptes Rendus Chimie, 2014, 17, 512-520.

36 R. Zboril, L. Machala, M. Mashlan and V. Sharma, Crystla Growth and Design, 2004, 4, 1317-1325.

37 L. Zhang, L. Shi, J. Huang, R. Gao and D. Zhang, ACS Catalysis, 2014, 4, 1753-1763.

38 X. Zhao, F. Li, B. Li, T. Zhang, Q. Teng, L. Wang, H. Wang and Y. Zhang, Journal of Physics and Chemistry of Solids, 2018, 
113, 134-141.

39 V. Escax, $P h D$ thesis, Université Paris VI, 2002.

40 G. Fornasieri, M. Aouadi, P. Durand, E. Rivière and A. Bleuzen, Chem. Comm., 2010, 46, 8061-8063.

41 M. Imperor-Clerc, D. Bazin, M.-D. Appay, P. Beaunier and A. Davidson, Chemistry of Materials, 2004, 16, 1813-1821.

42 I. Lopes, N. El Hassan, H. Guerba, G. Wallez and A. Davidson, Chemistry of Materials, 2006, 18, 5826-5828.

43 J. Van der Meer, I. Bardez-Giboire, C. Mercier, B. Revel, A. Davidson and R. Denoyel, Journal of Physical Chemistry C, 2010, 114, 3507-3515.

44 P. Durand, G. Fornasieri, C. Baumier, P. Beaunier, D. Durand, E. Rivière and A. Bleuzen, Journal of Materials Chemistry, 2010, 20, 9348-9354.

45 E. Delahaye, R. Moulin, M. Aouadi, V. Trannoy, P. Beaunier, G. Fornasieri and A. Bleuzen, Chemistry - A European Journal, 2015, 21, 16906-16916.

46 R. Moulin, E. Delahaye, A. Bordage, E. Fonda, J.-P. Baltaze, P. Beaunier, E. Rivière, G. Fornasieri and A. Bleuzen, European Journal of Inorganic Chemistry, 2017, 2017, 1303-1313.

47 G. Fornasieri, A. Bordage and A. Bleuzen, European Journal of Inorganic Chemistry, 2018, 2018, 259-271.

48 M. Aouadi, G. Fornasieri, V. Briois, P. Durand and A. Bleuzen, Chemistry - A European Journal, 2012, 18, 2617-2623.

49 V. Trannoy, PhD thesis, Université Paris-Saclay, 2015.

50 V. Briois, C. La Fontaine, S. Belin, L. Barthe, T. Moreno, V. Pinty, A. Carcy, R. Girardot and E. Fonda, Journal of Physics: Conference Series, 2016, 712, 012149.

51 A. Bleuzen, C. Lomenech, V. Escax, F. Villain, F. Varret, C. Cartier dit Moulin and M. Verdaguer, Journal of the American Chemical Society, 2000, 122, 6648-6652.

52 A. Bleuzen, J.-D. Cafun, A. Bachschmidt, M. Verdaguer, P. Münsch, F. Baudelet and J.-P. Itié, Journal of Physical Chemistry $C, 2008,112,17709-17715$.

53 X. Liu and C. T. Prewitt, Physical and Chemistry of Minerals, 1990, 17, 168-172.

54 A. Bordage, V. Trannoy, O. Proux, H. Vitoux, R. Moulin and A. Bleuzen, Physical Chemistry Chemical Physics, 2015, 17,
17260-17265.

55 P. J. Murray and J. W. Linnett, Journal of Physics and Chemistry of SOlids, 1976, 37, 619-624.

56 P. Dutta, M. Seerha, S. Thota and J. Kumar, Journal of Physics: Condensed Matter, 2008, 20, 015218.

57 G. Wang, X. Shen, J. Horvat, B. Wang, H. Liu, D. Wexler and J. Yao, The Journal of Physical Chemsitry C, 2009, 113, 43574361.

58 Y. I. Kim, D. Kim and C. S. Lee, Physica B, 2003, 337, 42-51.

59 X. Li and C. Kutal, Journal of Alloys and Compounds, 2003, 349, 264-268.

60 L. Garcìa-Cerda, V. Torres-Garcìa, J. Matutes-Aquino and O. Ayala, Valenzuela, Journal of Alloys and Compounds, 2004, 369, 148-151.

61 D. Carta, M. Casula, A. Falqui, D. Loche, G. Mountjoy, C. Sangregorio and A. Corrias, Journal of Physical Chemistry C, 2009, 113, 8606-8615.

62 S. Nappini, E. Magnano, F. Bondino, I. Pis, A. Barla, E. Fantechi, F. Pineider, C. Sangregoria, L. Vaccari, L. Venturelli and P. Baglioni, The Journal of Physical Chemistry C, 2015, 119, 25529-25541.

63 U. Wrongpratat, S. Maensiri and E. Swatsitang, Microelectronic Engineering, 2015, 146, 68-75.

64 V. Trannoy, L. Altenschmidt, G. Fornasieri, A. Bordage, E. Rivière, P. Beaunier and A. Bleuzen, ChemNanoMat, 2018, 4, 1254-1261.

65 C. Aparicio, L. Machala and Z. Marusak, Journal of Thermal Analysis and Calorimetry, 2012, 110, 661-669.

66 C. W. Ng, J. Ding, L. Wang, L. M. Gan and C. Quek, Journal of Physical Chemistry A, 2000, 104, 8814-8822.

67 C. W. Ng, J. Ding, Y. Shi and L. M. Gan, Journal of Physics and Chemsitry of Solids, 2001, 62, 767-775.

68 V. Trannoy, M. Faustini, D. Grosso, S. Mazerat, F. Brisset, A. Dazzi and A. Bleuzen, Beilstein Journal of Nanotechnology, 2014, 15, 1933-1943.

69 V. Trannoy, M. Faustini, D. Grosso, F. Brisset, P. Beaunier, E. Rivière, M. Putero and A. Bleuzen, Nanoscale, 2017, 9, 5234-5243. 


\section{Towards the synthesis of mixed oxides with controlled stoichiometry from Prussian Blue analogues}

Virgile Trannoy, ${ }^{\text {af }}$ Amélie Bordage, ${ }^{* a}$ Jordan Dezalay, ${ }^{a}$ Romuald Saint Martin, ${ }^{a}$ Eric Rivière, ${ }^{\mathrm{a}}$ Patricia Beaunier, ${ }^{\mathrm{b}}$ Cédric Baumier, ${ }^{\mathrm{c}}$ Camille La Fontaine, ${ }^{\mathrm{d}}$ Giulia Fornasieri, ${ }^{\mathrm{a}}$ and Anne Bleuzen ${ }^{\mathrm{a}}$

a ICMMO, Université Paris-Sud, Université Paris-Saclay, CNRS, Rue du doyen Georges Poitou, 91405 Orsay Cedex, France. Tel: +33 1691532 07; E-mail: anne.bleuzen@u-psud.fr

${ }^{\mathrm{b}}$ Sorbonne Université, CNRS, Laboratoire de Réactivité de Surface, LRS, F-75005 Paris, France

${ }^{c}$ Centre des Sciences Nucléaires et de la Matière, Université Paris-Sud, CNRS/IN2P3, Université ParisSaclay, 91405 Orsay Cedex, France

d Synchrotron SOLEIL, Saint Aubin, 91190 Gif-sur-Yvette, France

$\ddagger$ Present address : ILV, Université Versailles Saint-Quentin en Yvelines, UMR CNRS 8180, 45 avenue des

Etats-Unis, 78035 Versailles Cedex, France

\section{SUPPLEMENTARY INFORMATION}




\section{ESI 1 - Evidence by Infra-Red spectroscopy of a thermally-induced charge transfer in CoFe below $300^{\circ} \mathrm{C}$}

Middle infra-red spectroscopy measurements were performed on the precursor PBA (CoFe) and on the calcinated samples. We used a VERTEX70 spectrometer (Brüker) in the reflexion mode, with a resolution of $4 \mathrm{~cm}^{-1}$.

The spectra of CoFe in the early stages of calcination are displayed in figure S1; the assignment of the IR spectral features is done according to literature [s1-s4]. The first band centred at $2157 \mathrm{~cm}^{-1}$ is the signature of a Co"-NC-Fe ${ }^{\prime \prime \prime}$ linkage in a PBA. While heating up to $200^{\circ} \mathrm{C}$, the intensity of this band is decreasing, while two bands appear around $2120 \mathrm{~cm}^{-1}$ and $2090 \mathrm{~cm}^{-1}$; they are respectively characteristic of the $\mathrm{Co}^{\prime \prime \prime}-\mathrm{NC}-\mathrm{Fe}^{\prime \prime}$ and $\mathrm{Co}^{\prime \prime}-\mathrm{NC}-\mathrm{Fe}^{\prime \prime}$ linkages in a PBA. This indicates that prior the decomposition of the cyanide bridge around $300^{\circ} \mathrm{C}$, a thermally induced charge transfer from $\mathrm{Co}{ }^{\prime \prime}-\mathrm{NC}-\mathrm{Fe}^{\mathrm{III}}$ towards $\mathrm{Co}^{\prime \prime \prime}-\mathrm{NC}-\mathrm{Fe}^{\prime \prime}$ occurs. The presence of these two linkages explain the two mass losses observed by TDA/TGA between $240^{\circ} \mathrm{C}$ and $330^{\circ} \mathrm{C}$, which correspond to the decomposition of each kind of $\mathrm{Co}-\mathrm{NC}-\mathrm{Fe}$ linkages in the PBA.

Also, as (i) all IR bands in the cyanide stretching vibration range can definitely be assigned to cyanide in Co-NC-Fe environments with different oxidation states of the transition metal ions and (ii) no band corresponding to $\mathrm{CO}$ vibration appears on the spectrum, the presence of cyanate can be ruled out.

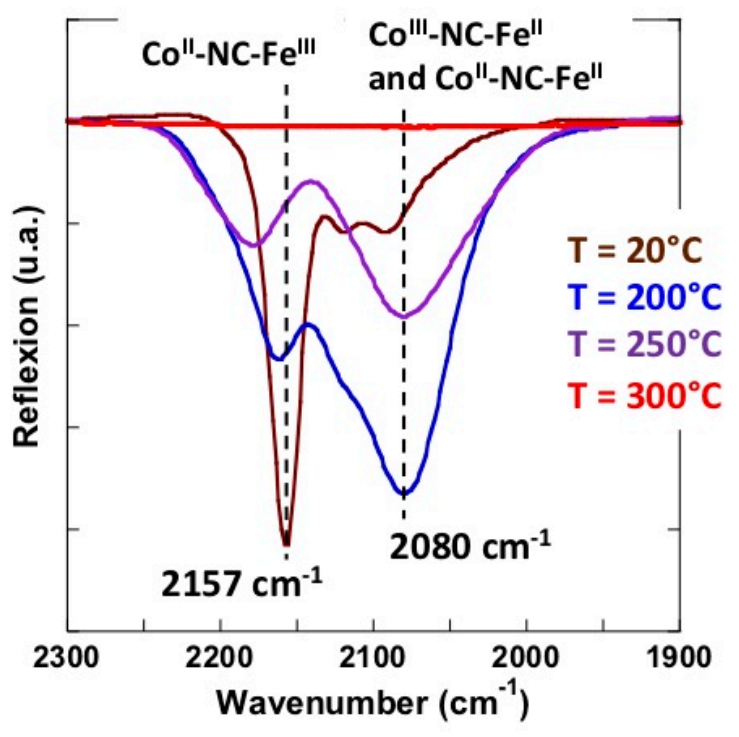

Figure S1. Infrared spectra on the cyanide bridge vibration range of CoFe before $\left(20^{\circ} \mathrm{C}\right)$ and during early calcination before the cyanide bridge decomposition $\left(200^{\circ} \mathrm{C}, 250^{\circ} \mathrm{C}\right.$ and $\left.300^{\circ} \mathrm{C}\right)$.

[s1] O. Sato, Y. Einaga, A. Fujishima and K. Hashimoto, Inorganic Chemistry, 1999, 38, 44054412. (and references within)

[s2] R.O. Lezna, R. Romagnoli, N.R. de Tacconi and K. Rajeshwar, Journal of Physical Chemistry $B, 2002,106,3612-3621$. (and references within)

[s3] N. Shimamoto, S-I. Ohkoshi, O. Sato and K. Hashimoto, Inorganic Chemistry, 2002, 41, 678684.

[s4] J. Lejeune, J-B. Brubach, P. Roy and A. Bleuzen, Comptes Rendus Chimie, 2014, 17, 534540. 
ESI 2 - Complete set of X-ray diffraction patterns between $300^{\circ} \mathrm{C}$ and $900^{\circ} \mathrm{C}$

The CoFe-TTXXX samples (TT = Thermal Treatment; XXX= calcination temperature) were obtained after the calcination of CoFe at different temperatures in order to investigate in details the calcination process. The whole set of XRD patterns are displayed in Figure S2.

Figure S2. XRD patterns of the CoFe-TTXXX samples between $300^{\circ} \mathrm{C}$ and $900^{\circ} \mathrm{C}$

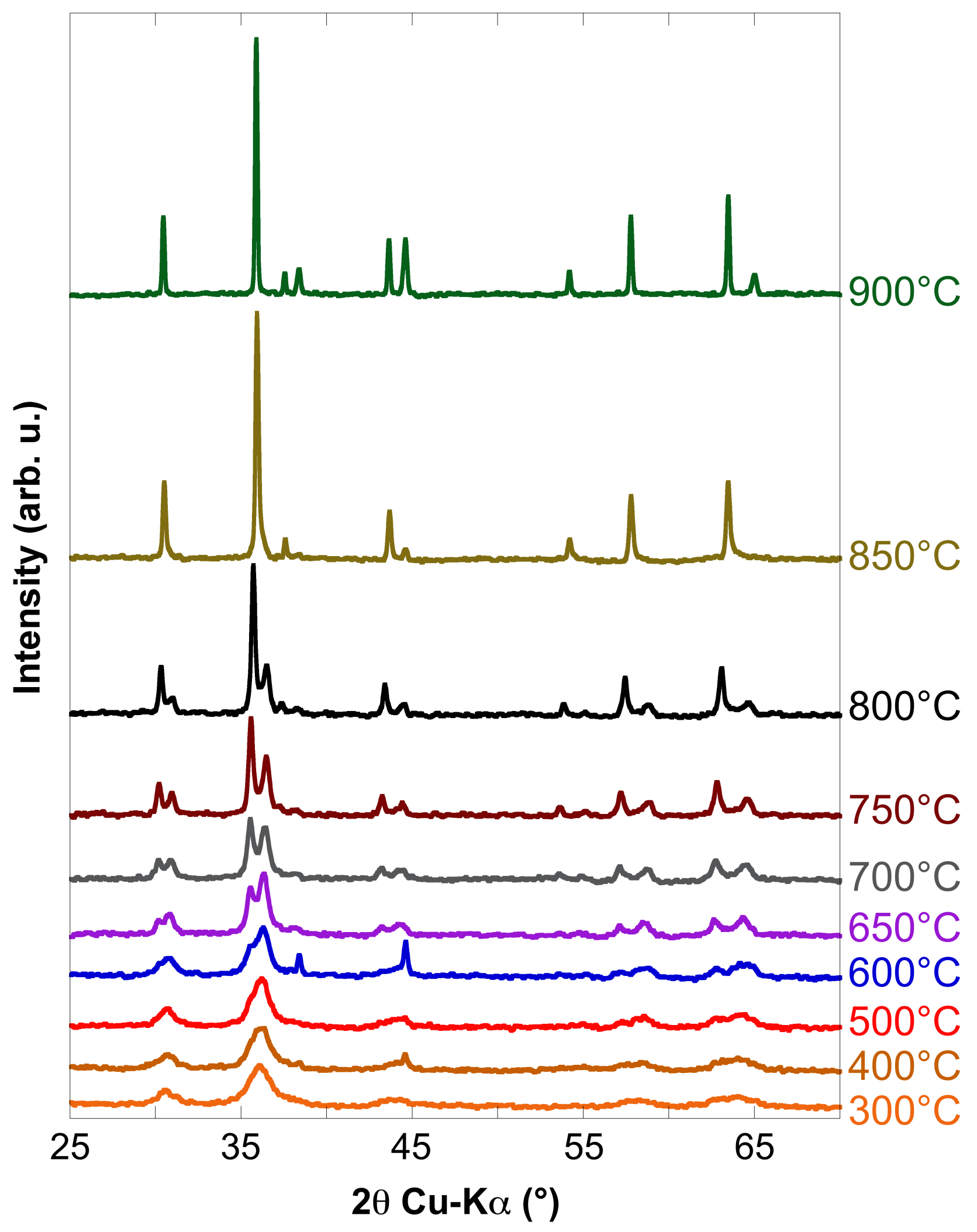

